\title{
SHORT-TERM RECOVERY OF CUSHION PLANT COMMUNITIES AFTER FIRE ON THE CENTRAL PLATEAU, TASMANIA
}

\author{
by Morgan C. Harding and Jamie B. Kirkpatrick \\ (with two text-figures, five plates and two tables)
}

\begin{abstract}
Harding, M.C. \& Kirkpatrick, J.B. 2018 (14:xii) Short-term recovery of cushion plant communities after fire on the Central Plateau, Tasmania. Papers and Proceedings of the Royal Society of Tasmania 152: 9-15. https://doi.org/10.26749/rstpp.152.9 ISSN: 0080-4703. Discipline of Geography and Spatial Sciences, School of Technology, Environments and Design, University of Tasmania, Private Bag 78, GPO Hobart, Tasmania, Australia $7001\left(\mathrm{MCH}, \mathrm{JK}^{*}\right)$. * Author for correspondence. Email: J.Kirkpatrick@utas.edu.au

There is slow or no regeneration of many Tasmanian alpine plant species after fire. At the decades scale cushion plants recover well, but there are no data on their short-term recovery. We determine the recovery of individual cushion bolsters and bolster communities at three locations on the Central Plateau of Tasmania burned less than five years before our repeat photography. Most cushions were scorched at the surface and perimeter rather than deeply combusted. Except where the bolsters were most intensively burnt, they revegetated within two years of fire. Cushion species extended their cover on the burned bolster surfaces at greater than twice the rate of all other species. Cushion segments that appeared to be deeply combusted during fire did not recover vegetatively.
\end{abstract}

Key Words: cushion plant, bolster plant, fire recovery, Tasmania.

\section{INTRODUCTION}

Bolsters are a dense assemblage of cushion plant individuals that coalesce to form a single sub-hemispherical structure (Curtis 1963, Gibson 1991, Kirkpatrick 1997). Due to their compaction and extremely short internodes, bolsters have a smooth, hard surface that may extend up to one or more metres in diameter and can be composed of many individuals and species (Curtis 1963, Gibson 1991, Kirkpatrick 1997). The Tasmanian endemic, Abrotanella forsteroides (Hook.f.) Benth., is the characteristic cushion of the eastern mountains, including the Central Plateau, where it is often mixed in bolster mosaics with a glaucous cushion, Pterygopappus lawrencei Hook.f. (Kirkpatrick 1997). Dracophyllum minimum F.Muell., Phyllachne colensoi (Hook.f.) Bergr. and Donatia novae-zelandiae Hook.f. are other frequent and widespread cushion species (Kirkpatrick et al. 1985, Kirkpatrick 1997), roughly distributed east to west respectively across the central and western mountains (Kirkpatrick 1982).

Efficient mechanisms for water uptake and a high absorption capacity, allow cushion bolsters to maintain a high water content (Gibson 1991). High water content and a smooth surface combine to make combustion rare (Kirkpatrick 1997). Adventive buds below the surface in Abrotanella, Donatia and Phyllachne cushions enable re-sprouting of foliage after complete surface heat-scorch (Kirkpatrick 1997).

A low fire frequency in Tasmanian alpine areas has allowed fire-intolerant species to dominate much of the landscape (Kirkpatrick et al. 2002, Kirkpatrick et al. 2010). With the exception of Dracophyllum minimum, cushion plants are resilient to fire at the decades scale (Kirkpatrick \& Dickinson 1984, Kirkpatrick et al. 2002, Kirkpatrick et al. 2010, Kirkpatrick \& Bridle 2013). Fire may be necessary to prevent their loss by smothering by taller species in some of the more productive parts of their ranges. We have no data on short-term bolster community recovery after fire. Mean annual temperature has increased while mean annual rainfall has decreased since 1970 (Calder \& Kirkpatrick 2008, Bureau of Meteorology 2018). Warming and drying has led to increased fire frequency and area burned as predicted by King et al. (2013). Extensive fires occurred on the Central Plateau in 2013 (7000 ha) and 2016 (13 $000 \mathrm{ha})$. There was public alarm at the potential loss of Pencil Pines (Athrotaxis cupressoides D.Don) and cushion plants (Press 2016), so it is important to understand the contingencies of short-term recovery.

The present study documents changes in individual cushion bolsters and bolster communities at three locations in the Central Plateau region of the Tasmanian Wilderness World Heritage Area burned 1-4 years previous to final observations.

\section{METHODS}

\section{Study area}

Three sets of photographs were taken of cushion bolsters and cushion bolster communities at sites burned either in 2013 or 2016. The Lake Mackenzie study site is located in the Central Plateau Conservation Area south of Mt Parmeener on the Great Western Tiers escarpment. The area was burned between 19 January 2016 and 27 January 2016. The surface geology of this area is Jurassic dolerite. The Poatina study site is situated slightly southeast of Cramps Bay and adjacent to the Poatina Road within the Great Lake Conservation Area. The fire burned between 29 November 2012 and 6 January 2013. The study area was very close to the point of ignition. The surface geology of this area is Jurassic dolerite. The Walls of Jerusalem study area is situated within the Walls of Jerusalem National Park on the western edge of the Central Plateau, with The Temple forming the eastern pillar of Damascus Gate, opposite Solomon's Throne. The area was burned on 3 January 2013. The surface geology 
of the study site is a finely textured facies of the Parmeener supergroup of Permian/Triassic rocks.

\section{Data collection}

Shortly after each of the three fires, oblique photographs were taken of individual bolsters and bolster communities (table 1). These scenes were rephotographed in March and April 2017 (table 1). Location and orientation of each scene were recorded using a GPS and magnetic compass.

\section{Analysis}

Due to the high level of reproducibility between the older and 2017 observation images, we compared change in individual bolsters. Selected jpeg files of individual bolster images were edited in Adobe Photoshop Lightroom ${ }^{\oplus}$ (2015.10 Release) to remove background colour by reducing all HSL (Hue, Saturation and Luminance) channels other than green to the -100 level. Colour removal was undertaken on all individual bolster images except for plate 1, (left image, 2017) and plate 5 (left image, 2017) as it was difficult to differentiate between cushion species and coloniser species using this technique on that image. The aspect ratio of the images was as-shot out of camera with a 4 × 3 horizontal to vertical aspect ratio. Twelve vertical and 16 horizontal grid lines were superimposed over each image. To estimate the proportion of each image occupied by the whole bolster area, total cover was measured for each grid cell with any bolster cover at either date. Cushion species cover, coloniser species cover and dead or absent vegetation were expressed as a proportion of the total area of these cells.

\section{RESULTS}

In the image from Lake Mackenzie in 2016, a cushion heath occupies the foreground and middle ground (pl. 1). The cushion heath is mostly unburned; however, the perimeter was subject to intense scorching and desiccation and displays a moderate to heavy degree of erosion. A segment of a cushion in the lower right quarter of the image was more severely burned. Large areas of soil are exposed by burning around this cushion. The cushion mosaic is interspersed with Poa spp., Baloskion australe (R.Br.) B.G. Briggs \& L.A.S. Johnson and a single Richea scoparia Hook.f. shrub. The dominant cushion species is $A$. forsteroides with patches of P. lawrencei.

By 2017, the heavily burned areas between and outside the cushions were mostly recolonised by grass and herb species; however, areas of bare soil still remain (pl. 1). The perimeter of the unburned cushion has evidence of erosion. The segment of cushion more severely burned in the 2016 image was necrotic. Most of the biomass within the cushion heath remains and appears predominantly undisturbed. Numerous patches of Empodisma minus (Hook.f.) L.A.S. Johnson \& D.F. Cutler and Poa species are present within the bolster matrix.

A pair of Poatina images capture an area spanning less than $5 \times 5$ m with approximately $30 \%$ of the scene occupied by a shallow bare depression (pl. 2). In the 2013 image the depression is full of water. Cushions are the dominant lifeform. The dominant cushion species is $A$. forsteroides with patches of $P$. lawrencei. The dead remains of woody shrubs are present, as well as live grasses and herbs, including Astelia alpina R.Br., B. australe, Rytidosperma pauciflorum (R.Br.) H.E. Connor \& E. Edgar and Poa species. Charred areas of exposed earth provide evidence of recent burning. Desiccated and fresh macropod droppings are visible. The fire had the greatest impact between the more elevated cushion bolsters. Burning of cushion plants is evident along their margins.

By 2017, the scene is dominated by grasses, especially in areas that were more heavily fire-affected in the 2013 image. While bolsters appear to be in good condition, they have been colonised by monocotyledons. These include all species identified in the 2013 image, with the addition of Deyeuxia quadriseta (Labill.) Benth. and Lepidosperma filiforme Labill.. E. minus is common. Monocotyledons do not appear to be heavily grazed as evidenced by intact inflorescences. No woody shrub regrowth is evident.

A second pair of Poatina images captures an area spanning less than $5 \times 5 \mathrm{~m}$ with approximately $10 \%$ of

TABLE 1 - Site and image metrics for Lake Mackenzie, Poatina and Walls of Jerusalem site

\begin{tabular}{|c|c|c|c|c|c|c|c|c|}
\hline Location & $\begin{array}{c}\text { GPS } \\
\text { coordinate } \\
\text { GDA94/55G }\end{array}$ & $\begin{array}{l}\text { Direction of } \\
\text { photograph } \\
\left({ }^{\circ}\right)\end{array}$ & $\begin{array}{l}\text { Fire start } \\
\text { date }\end{array}$ & $\begin{array}{l}\text { Fire end } \\
\text { date }\end{array}$ & $\begin{array}{l}\text { Fire span } \\
\text { (days) }\end{array}$ & Photo 1 & Photo 2 & $\begin{array}{c}\text { Time } \\
\text { between } \\
\text { (days) }\end{array}$ \\
\hline $\begin{array}{l}\text { Lake } \\
\text { MacKenzie }\end{array}$ & $\begin{array}{l}0449231 \\
5386577\end{array}$ & 311 & 19-Jan-16 & 4-May-16 & 106 & 27-Jan-16 & 29-Mar-17 & 427 \\
\hline $\begin{array}{l}\text { Poatina } \\
\text { (1) }\end{array}$ & $\begin{array}{l}0487322 \\
5361824\end{array}$ & 45 & 29-Nov-12 & 6-Jan-13 & 38 & 9-Apr-13 & 5-Mar-17 & 1426 \\
\hline $\begin{array}{l}\text { Poatina } \\
\text { (2) }\end{array}$ & $\begin{array}{l}0487310 \\
5361810\end{array}$ & 45 & 29-Nov-12 & 6-Jan-13 & 38 & 9-Apr-13 & 5-Mar-17 & 1426 \\
\hline $\begin{array}{l}\text { Poatina } \\
\text { (3) }\end{array}$ & $\begin{array}{l}0487321 \\
5361816\end{array}$ & 45 & 29-Nov-12 & 6-Jan-13 & 38 & 9-Apr-13 & 5-Mar-17 & 1426 \\
\hline $\begin{array}{l}\text { Walls of } \\
\text { Jerusalem }\end{array}$ & $\begin{array}{l}0441906 \\
5369459\end{array}$ & 39 & 3-Jan-13 & 3-Jan-13 & 1 & 22-Feb-13 & 2-Apr-17 & 1500 \\
\hline
\end{tabular}



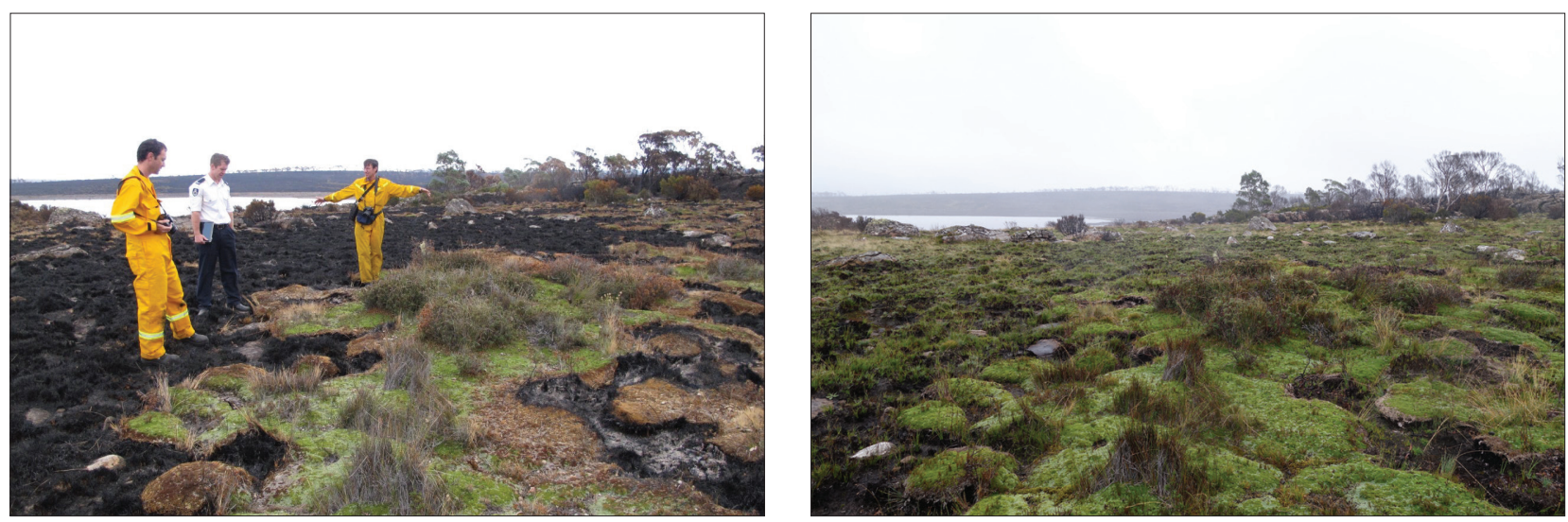

PLATE 1 - Looking towards Lake McKenzie. Left: 27 January 2016 (Jayne Balmer), Right: 29 March 2017 (Morgan Harding).
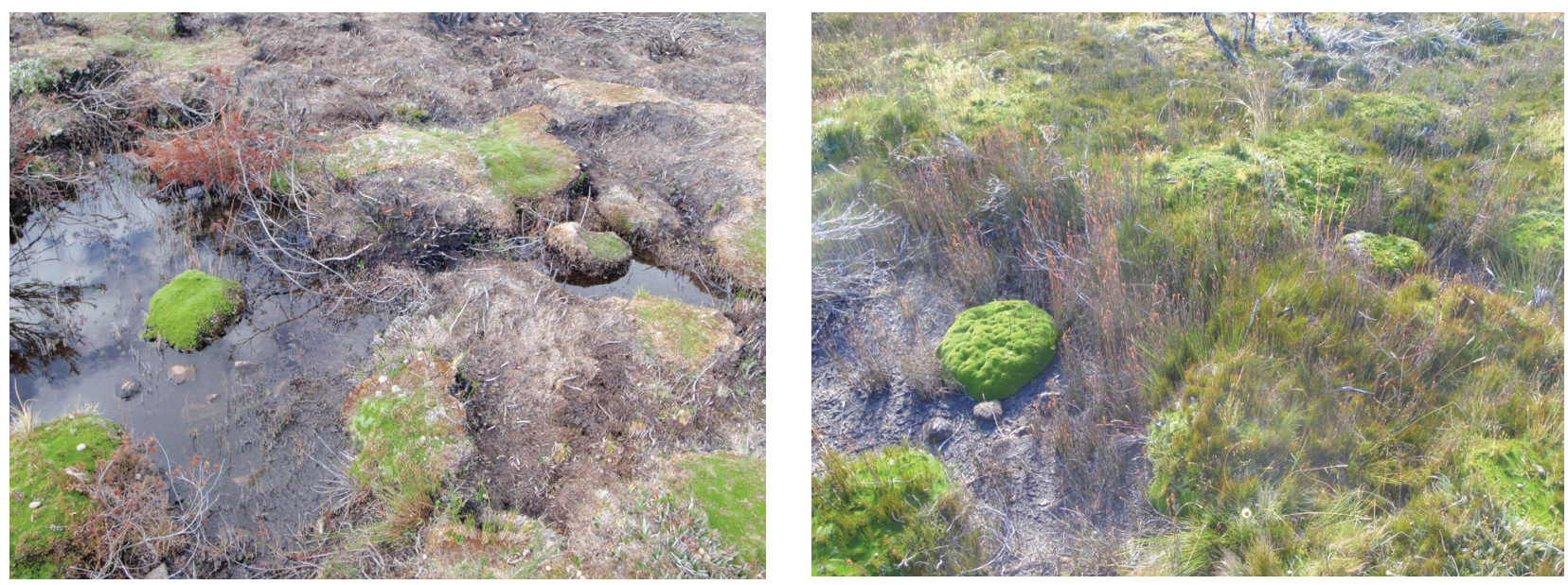

PLATE 2 — Poatina Road 1. Left: 9 April 2013 (Jamie Kirkpatrick), Right: 5 March 2017 (Jamie Kirkpatrick).

the scene occupied by a shallow depression (pl. 3). In 2013, cushions were the dominant recognisable lifeform. The dominant cushion species is $A$. forsteroides. There is an absence of taller lifeforms. There are dead stems of woody plants. Monocotyledons, including A. alpina, L. fliforme and Poa occur among bolsters, charred areas and exposed soil. Desiccated and fresh macropod droppings are visible. Burning of cushion plants appears to have been restricted to the margins of the bolsters.

By 2017, the overall scene was dominated by monocotyledons, especially in areas that were more severely burned in 2013. The cushions were heavily colonised, particularly by E. minus. There were few macropod scats. Woody shrubs began to recover from the impact of burning.

Another pair of Poatina images depicts a single bolster spanning less than $3 \times 3 \mathrm{~m}$ (pl. 4). In 2013, roots protruded from two edges of the $A$. forsteroides bolster. The bolster edges appear eroded, exposed and desiccated. Much of the cover of the bolster appears scorched. A light scatter of short monocotyledons and herbs is evident on the exposed soil. E. minus and L. filiforme were the only two monocotyledon species present within the bolster matrix. Euchiton traversii (Hook.f.) Holub. and an unidentified species were the only herbs. Beyond the eroded area in which the bolster is located, monocotyledons are dominant.

By 2017, grass and herb cover was higher than in 2013 in the immediate proximity of the cushion. Onceexposed edges of the bolster were no longer visible due to colonisation of E. minus, B. australe, Dichelachne spp. and Rytidosperma pauciflorum. Euchiton traversii persisted from 2013. The cushion displayed a high degree of secondary species colonisation.

The Walls of Jerusalem cushion images display a scene of approximately $2 \times 2 \mathrm{~m}$ (pl. 5). In 2013, the area surrounding the two $A$. forsteroides bolsters consists of approximately $30 \%$ burned and exposed roots and soil, and $70 \%$ short grasses. The bolster surface was scorched, although some green shoots of $A$. forsteroides are evident. Hydrocotyles sibthorpioide Lam., Lycopodium fastigiatum R.Br. and Oreomyrrhis ciliata Hook.f. grow on the bolster surface. The area separating the two cushion bolsters was occupied by Poa. The upper centre of the larger bolster appears dead. By 2017, the bolsters had recovered, apart from a new necrotic lesion between the two cushions. Gaultheria tasmanica (Hook.f.) D.J. Middleton joined the colonisers of 2013. 

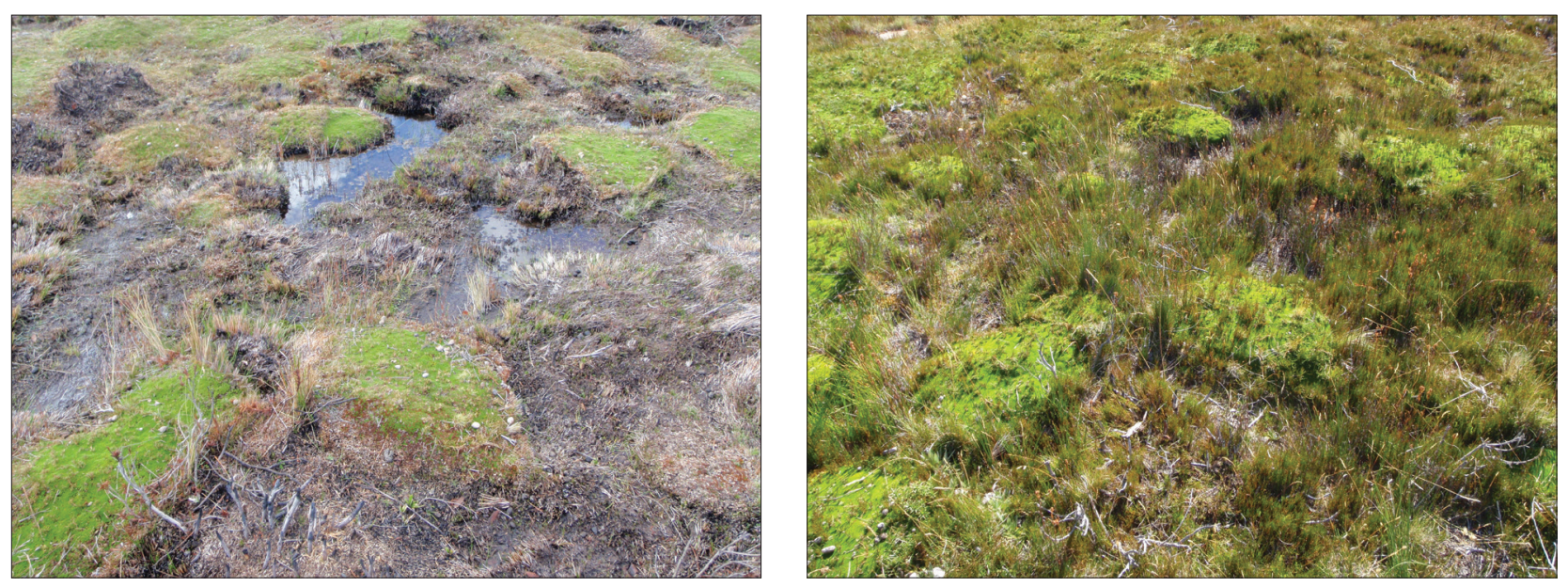

PLATE 3 - Poatina Road 2. Left: 9 April 2013 (Jamie Kirkpatrick), Right: 5 March 2017 (Jamie Kirkpatrick).
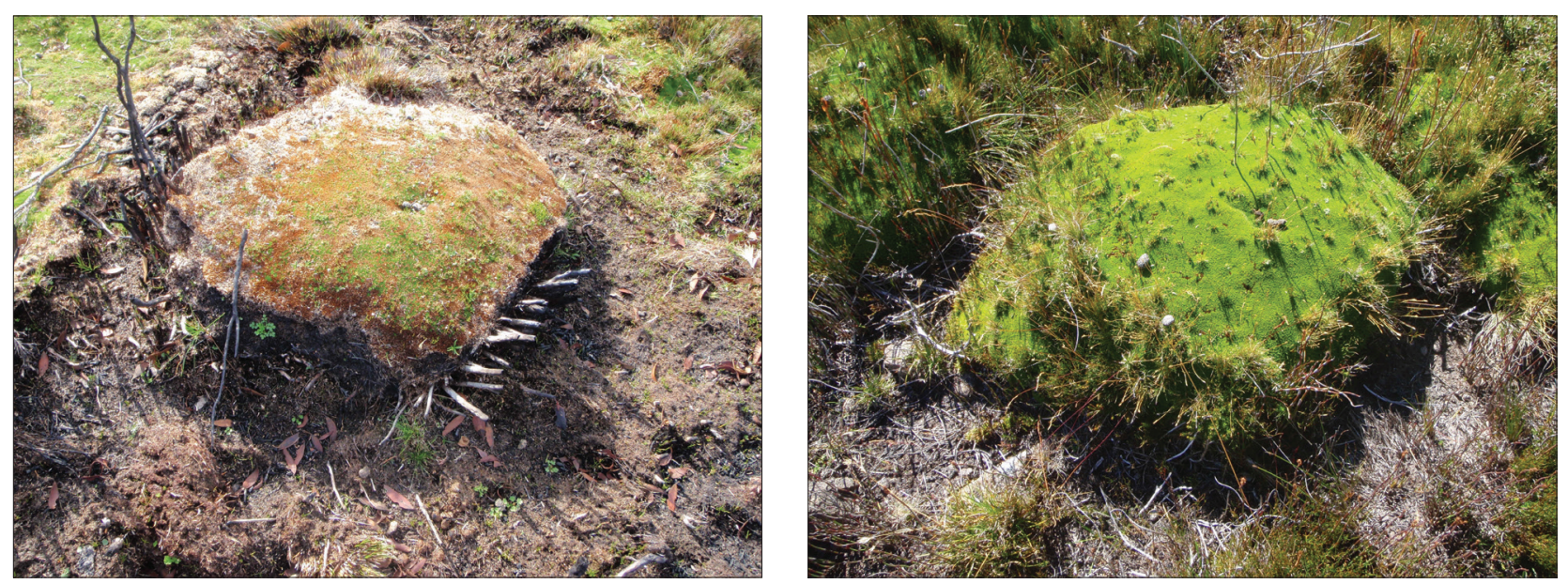

PLATE 4 - Poatina Road 3. Left: 9 April 2013 (Jamie Kirkpatrick), Right: 5 March 2017 (Jamie Kirkpatrick).
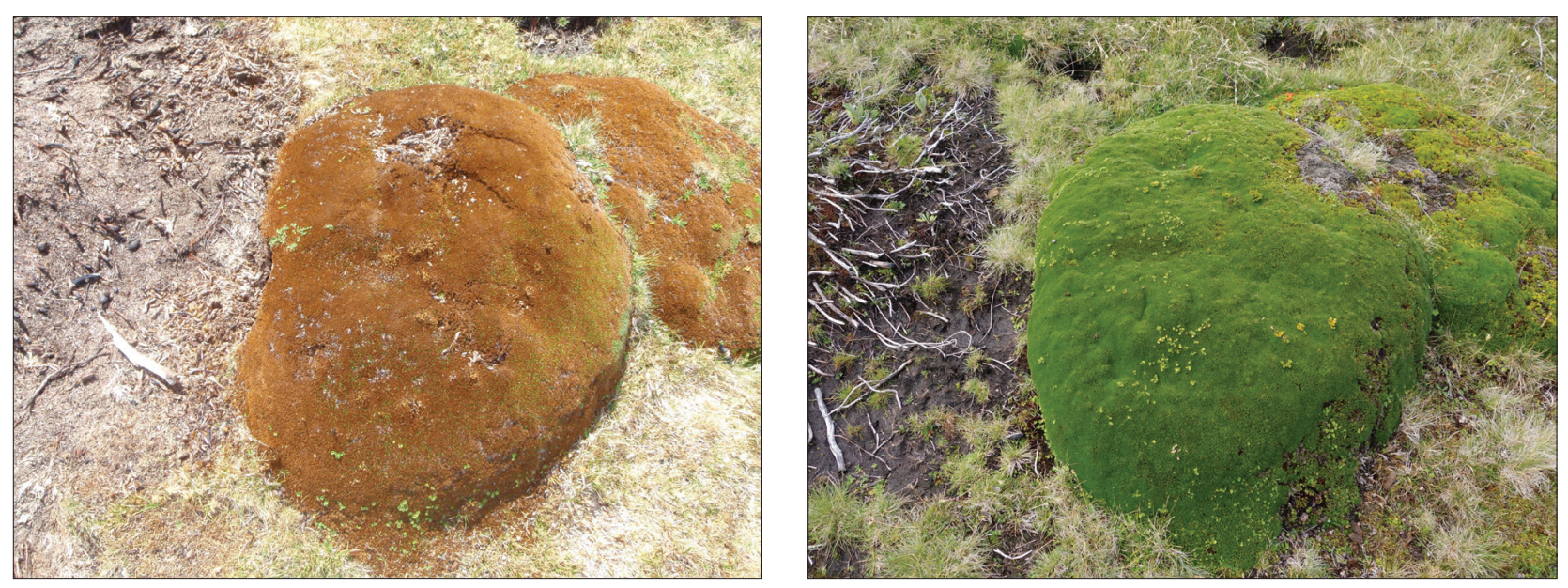

PLATE 5 - Walls of Jerusalem. Left: 22 February 2013 (Jamie Kirkpatrick), Right: 2 April 2017 (Morgan Harding). 
Greater richness of coloniser species was observed on bolsters in all five 2017 observation images than on the earlier images (table 2). Empodisma minus was identified in burned areas in most 2017 images but not in earlier images. Deyeuxia quadriseta was only visible in Poatina 2017 images. Where Astelia alpina was present, it was identified at both times. Poa spp. were present in paired images at all places. Coronidium scorpioides was identified at Poatina where it was observed in both paired images. Hydrocotyle sibthorpioide, Lycopodium fastigiatum and Oreomyrrhis ciliata were only identified at the Walls of Jerusalem, where they were observed in both images.

Coloniser species richness was greater in 2017 than earlier (table 2). There was a natural logarithmic increase in species richness from time of burn (fig. 1). Bare ground decreased, as cushion cover increased at greater than twice the rate of other cover (fig. 2).

\section{DISCUSSION}

The rapid recovery of Rytidosperma pauciflorum, Deyeuxia quadriseta, Empodisma minus, Astelia alpina and Poa spp. is consistent with decadal changes after fire in both cushiondominated vegetation and alpine heathland (Kirkpatrick \& Dickinson 1984, Kirkpatrick et al. 2010). The rhizomatous habit of $E$. minus makes it particularly likely to evince a rapid recovery, while the hemicryptophyte life form of other grasses facilitates survival and regeneration where fire does not penetrate the surface. The resistance and resilience of Abrotanella forsteroides in the early years after fire is also consistent with the results of decadal scale observations (Kirkpatrick \& Dickinson 1984). The resilience of cushion species following complete surface scorching has been previously noted (Kirkpatrick \& Dickinson 1984, Kirkpatrick 1997, Kirkpatrick et al. 2010). It is a function of below surface buds in non-shrubby cushion species

TABLE 2 - Taxa observed on surfaces of bolster in Plates 1-5

\begin{tabular}{|c|c|c|c|c|c|c|c|c|c|c|}
\hline \multirow[t]{2}{*}{ Coloniser species } & \multicolumn{2}{|c|}{$\begin{array}{l}\text { Walls of } \\
\text { Jerusalem }\end{array}$} & \multicolumn{2}{|c|}{ Poatina (1) } & \multicolumn{2}{|c|}{ Poatina (2) } & \multicolumn{2}{|c|}{ Poatina (3) } & \multicolumn{2}{|c|}{$\begin{array}{c}\text { Lake } \\
\text { Mackenzie }\end{array}$} \\
\hline & 2013 & 2017 & 2013 & 2017 & 2013 & 2017 & 2013 & 2017 & 2016 & 2017 \\
\hline Astelia alpina & & & $\bullet$ & $\bullet$ & $\bullet$ & $\bullet$ & & & & \\
\hline Baloskion australe & & & $\bullet$ & $\bullet$ & & $\bullet$ & & $\bullet$ & & • \\
\hline Coronidium scorpioides & & & $\bullet$ & $\bullet$ & & & & & & \\
\hline Rytidosperma pauciflorum & & & $\bullet$ & & & $\bullet$ & & $\bullet$ & & \\
\hline Deschampsia cespitosa & & & & & & & & & & • \\
\hline Deyeuxia quadriseta & & & & $\bullet$ & & $\bullet$ & & & & \\
\hline Dichelachne spp. & & & & & & & & $\bullet$ & & \\
\hline Empodisma minus & & & & $\bullet$ & & $\bullet$ & & $\bullet$ & & - \\
\hline Erigeron pappocromus & & & & & & & & & & - \\
\hline Euchiton traversii & & & $\bullet$ & & & $\bullet$ & $\bullet$ & $\bullet$ & & \\
\hline Gaultheria tasmanica & & $\bullet$ & & & & & & & & \\
\hline Hydrocotyle sibthorpioides & $\bullet$ & $\bullet$ & & & & & & & & \\
\hline Lepidosperma filiforme & & & & $\bullet$ & $\bullet$ & $\bullet$ & $\bullet$ & & & \\
\hline Lycopodium fastigiatum & $\bullet$ & $\bullet$ & & & & & & & & \\
\hline Oreomyrrhis ciliata & • & $\bullet$ & & & & & & & & \\
\hline Poasp. & $\bullet$ & $\bullet$ & - & $\bullet$ & $\bullet$ & $\bullet$ & & & $\bullet$ & - \\
\hline Poranthera microphylla & & & & & & $\bullet$ & & & & \\
\hline Unidentified herb & $\bullet$ & & & & & & $\bullet$ & & & \\
\hline Species Richness & 4 & 5 & 6 & 7 & 3 & 9 & 3 & 5 & 1 & 5 \\
\hline
\end{tabular}




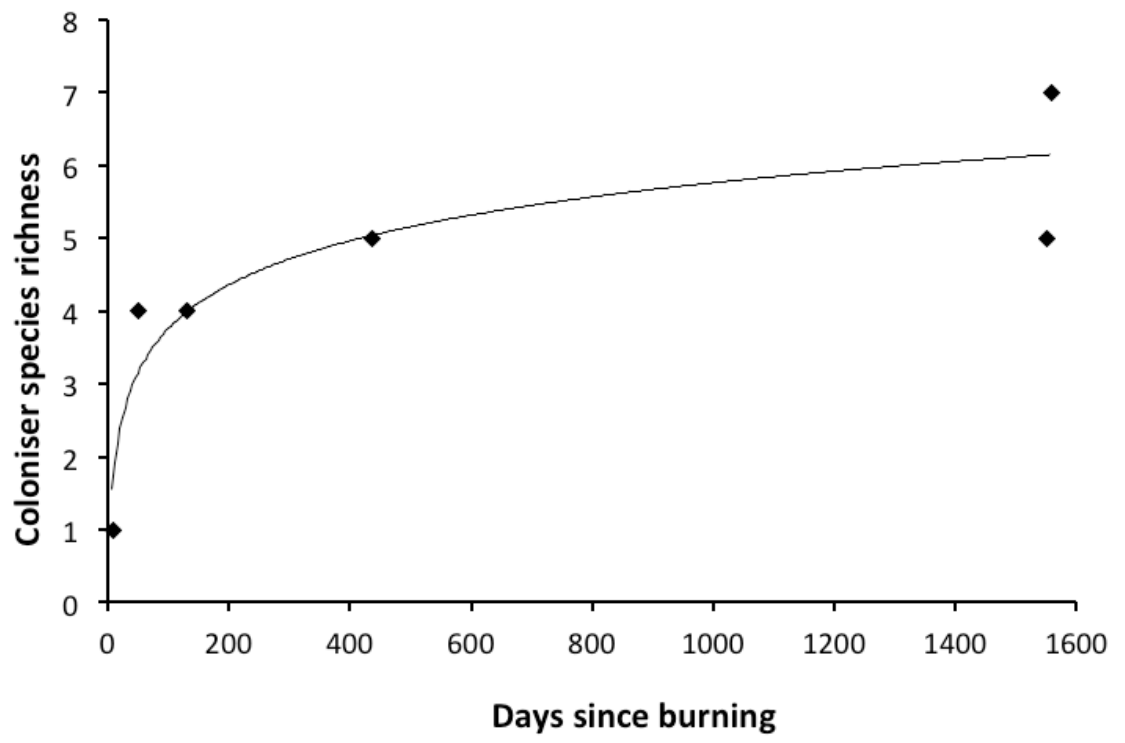

FIG. 1 - Mean richness of coloniser species in cushions for Lake Mackenzie, Poatina and Walls of Jerusalem sites by time since burning. $y=0.871 \ln (x)-0.257, R 2=0.842 . t$

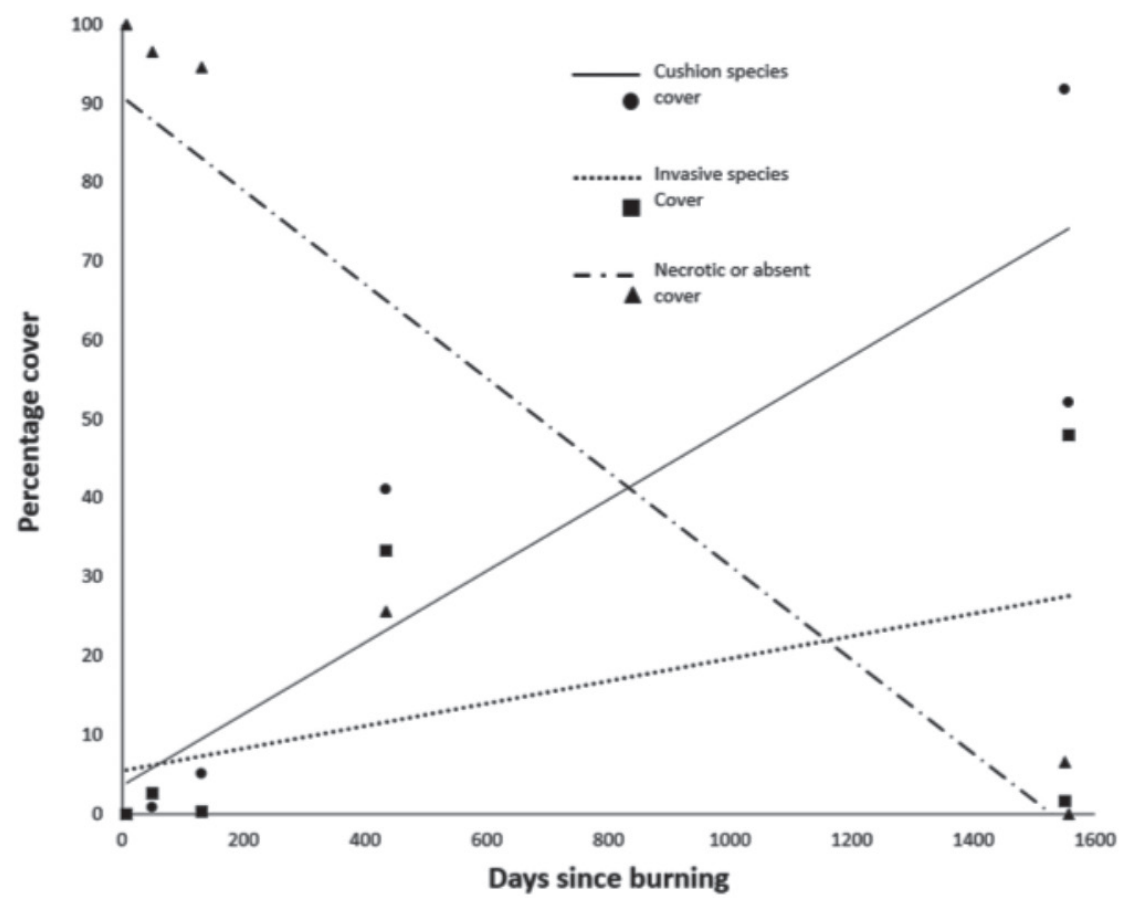

FIG. 2 - Temporal change in cushion plant cover, coloniser species cover and necrotic or absent vegetation cover on cushions. 
facilitating rapid vegetative regeneration (Kirkpatrick 1997).

Localised necrosis of a single cushion segment at Lake Mackenzie that was subject to combustion rather than scorching suggested an exception to post-fire resilience of cushions as understood in the literature. Vegetation growing around, between or within bolsters including, but not limited to, coloniser species appears to be able to generate enough heat during a fire to kill subsurface cushion plant buds. Severe and persistent effects of fire are suggested to have a greater impact on Tasmanian alpine vegetation than climatic changes (Kirkpatrick et al. 2010). It may be that cushions will benefit from low frequency and intensity fire through the opportunity to expand into areas previously dominated by shrubs (Kirkpatrick et al. 2010), as is indicated by our observations. However, in the overall context of alpine ecology such fires are undesirable.

\section{AKNOWLEDGEMENTS}

We thank Jayne Balmer in DPIPWE for the 2016 image from Lake Mackenzie. Maj-Britt di Folco helped us relocate the Poatina scenes. Lawson Harding assisted with image processing. We are grateful to the Foundation for National Parks \& Wildlife for organising crowdsource funding and to those who gave.

\section{REFERENCES}

Bureau of Meteorology. 2018: Climatic Change and Variability. Available at: http://www.bom.gov.au/ climate/change/index [Accessed 29 Jul. 2018].

Calder J.A. \& Kirkpatrick, J.B. 2008: Climate change and other factors influencing the decline of the Tasmanian cider gum (Eucalyptus gunnii). Australian Journal of Botany 56: 684-692.

Curtis, W. 1963: The Student's Flora of Tasmania Angiospermae: Lythraceae to Epacridaceae. 2nd ed. Tasmania: Government Printer: 58-60, 163-164.
Gibson, N. 1991: The anatomy and morphology of four Tasmanian cushion species. Papers and Proceedings of the Royal Society of Tasmania 31: 231-238.

King, K.J., Cary, G.J., Bradstock, R.A. \& MarsdenSmedley, J.B. 2013: Contrasting fire responses to climate and management: insights from two Australian ecosystems. Global Change Biology 19: 1223-1235.

Kirkpatrick, J.B. 1982: Phytogeographical analysis of Tasmanian alpine floras. Journal of Biogeography 9: 255-271.

Kirkpatrick, J.B. 1997: Alpine Tasmania. Melbourne: Oxford University Press: 58-63, 162-164.

Kirkpatrick, J.B. \& Bridle, K.L. 2013: Natural and cultural histories of fire differ between Tasmanian and mainland alpine vegetation. Australian Journal of Botany 65: 465-474.

Kirkpatrick, J.B., Bridle, K.L. \& Dickinson, K.J.M. 2010: Decade-scale vegetation change in burned and unburned coniferous heath. Australian Journal of Botany 58: 453-462.

Kirkpatrick, J.B., Bridle, K.L. \& Wild, A.S. 2002: Succession after fire in alpine vegetation on Mount Wellington, Tasmania. Australian Journal of Botany 50: $145-154$.

Kirkpatrick, J.B. \& Dickinson, K.J.M. 1984: The impact of fire on Tasmanian alpine vegetation and soils. Australian Journal of Botany 32: 613-629.

Kirkpatrick, J.B., Minchin, P.R. \& Davies, J.B. 1985: Floristic composition and macroenvironmental relationships of Tasmanian vegetation containing bolster plants. Vegetation 63: 89-96.

Press, A.J. 2016: Tasmanian Wilderness World Heritage Area Bushfire and Climate Research Project. Hobart: Tasmanian Government: 9.

(accepted 4 September 2018) 
